\title{
Access and Quality in Nigeria's Higher Education: Need for a Pragmatic Approach for Sustainable Transformation
}

\author{
Joy N. Njoku \\ Department of Educational Foundations, Guidance and Counselling, University of Calabar, Nigeria \\ E-mail: jnnjoku3@gmail.com
}

Received: 04-02- 2016

Accepted: 25-04-2016

Published: $30-04-2016$

doi:10.7575/aiac.ijels.v.4n.2p.62

URL: http://dx.doi.org/10.7575/aiac.ijels.v.4n.2p.62

\begin{abstract}
Access and quality of higher education are among the major criteria for assessing the product of any institution of higher learning. This paper discusses access and quality in Nigeria's higher education; need for a pragmatic approach for sustainable transformation'. It discusses problems of access in the areas of carrying capacity of universities, process of admission, poverty, location and corruption. The problems of quality were traced to poor recruitment procedure, inadequate infrastructure, poor funding, corruption and lack of adequate practical experience. The problems of quality also extended to poor research development and underutilization of research findings. Pragmatic approach to solving each of these problems was discussed which include abolishing policies that have not benefited the education system like quota system. The paper advocates for merit at this crucial stage of national development, at least seventy percent of admissions into tertiary institutions should be based on pure merit. Recruitment of academic and non-academic staff should be purely on merit. Funds should be made available for the provision of adequate infrastructure. Research findings and recommendations should be urgently appraised and utilized.
\end{abstract}

Keywords: Higher Education, Access, Quality, Pragmatic, Transformation

\section{Introduction}

Education is the bedrock for the development of people and nations and a sure means of sustainable transformation. The method or approach to education may differ from one country to the other. Some insist on the use of their indigenous languages to educate their people irrespective of course or subject while others have lingua franca which may be foreign to the citizens but must be learnt. Whichever way, education worldwide has been accorded great importance in social, moral, intellectual and cultural development of its citizenry.

Education is the act or process of imparting or acquiring general knowledge, developing the powers of reasoning and judgement and generally of preparing oneself or others intellectually for mature life. Amaele (2004) defined education as the process of transforming the raw human resources to the expected quality and standard to live and contribute effectively to the development of the society. Any education process that cannot translate to addressing and solving the problems of the society has lost its value. Nigeria has long before her independence embraced Western education and till now is still investing in education. However, it appears there is little or nothing to show for it in spite of huge human and material resources in the nation. What could the problem be? The revised version of National policy on Education (2004) stipulated equal educational opportunity for all children irrespective of tribe, religion, sex or disability. Yet there is disparity in access to education from primary to tertiary education. The rich has better access to education at all levels.

Research, according to Asiabaka (2006), is one of the tripartite functions of tertiary institutions and engine that propels national development. He recommended a well-articulated and focused research and development agenda in Nigeria. This recommendation and many others have not been adhered to. Many academicians have lost interest in research due to poor motivation and lack of funds to carry out their research. Many researches are conducted haphazardly and those who manage to conduct and conclude their research properly are discouraged because their findings are not utilized. Offices and libraries in Nigeria's tertiary institutions are littered with projects, dissertation and thesis of students. Lecturers only see their research work in prints most of the time and their findings and recommendations are never addressed. All these have contributed to poor quality outputs in higher institutions. To meet sustainable transformation these problems have to be addressed. Sustainability implies to endure or to continue into the future while transformation connotes radical change. Sustainable transformation in higher education therefore implies an enduring or lasting change. This paper addresses the problem of access and quality in higher education in Nigeria and advocates a pragmatic approach in dealing with these problems for a sustainable transformation. 


\section{Problem of Access to Higher Education in Nigeria}

Access to higher education implies availability of opportunities for candidates seeking admission into tertiary institutions to actually secure the admission. The problem of access into Nigerian Universities and other tertiary institutions has become a devastating one for many parents and their children or wards. Nigeria as a densely populated nation (about 160 million people) has over a third of its population made up of youths and the category of people still seeking for admission into one tertiary institution or the other. Every year the population of applicants seeking admission continues to rise. Available universities and other tertiary institutions cannot absorb all the qualified candidates. Ibrahim and Okeke (2015) reported that Prof Ruqayyatu Ahmed Rufa'i (former Minister of education) stated in the $2^{\text {nd }}$ Annual Conference of Association of West African Universities in Ghana held in 2013 that about $1.6 \mathrm{~m}$ Nigerians apply for admission into tertiary institutions every year and only about $1 / 3$ of the population is absorbed into the institutions due to multiple problems of available space, infrastructure, economy etc. Similarly Okoroafor (2013) in his article reported that only about $1 / 3$ of the population of applicants who write Unified Tertiary Matriculation Examination (UTME) every year succeed in gaining admission into institutions and courses of their choice. The problem of access does not end with the carrying capacity of the institutions. There are still many other hydra headed problems like the selection procedure of different institutions. Nigerians seeking admission into tertiary institutions are subjected to excessively difficult and unnecessary processes. The candidates start by making at least 5 Ordinary level credits in relevant subjects, apply for and write the UTME which covers 3 core subject areas and English language. Candidates must score a minimum of 180 out of 400 maximum points to qualify for Post UTME which is conducted by respective institutions. All these processes consume a lot of money and time which many candidates cannot afford. Every year access to higher institutions keeps getting tighter and tougher. The problem of Location (urban/rural settlements) has greatly affected access to higher education. Many candidates seeking admission from rural areas find it difficult to even register for UTME. Many of them travel long distances to have access to internet services. Most of such candidates are also disadvantaged most of the time because they may not be computer literate and may not have operated one in their life.

All these problems have led to mass exodus of Nigerian youths to other countries where they pay huge sums of money to acquire tertiary education. The admission procedure in Ghana for instance is very simple, once you pass your senior high school certificate exams; you make choice of institutions which will conduct their simple selection exams. Successful candidates are given admission.

The problem of quota system that is enshrined in Nigeria Constitution has led to inequality, deprivation and imbalance in access to higher education. The ratio of 40:40:20 in favour of merit, catchment and educationally less privileged states is a disservice to a country that is struggling to develop, Merit should have at least $70 \%$ before any other consideration can be made. There is no businessman that showcases his poor quality goods while hiding his best products. This is exactly what the quota system has left the nation with, from primary to tertiary institutions even extending to job opportunities. Many good candidates cannot secure admission with high scores while they see many they are better off in the Universities. What justifies this practice? There are good policies that can be implemented like 60:40\% for science and arts candidates respectively, 70:30 for technical and arts courses for universities and polytechnics respectively. Such policies are good for a developing nation but the implementations of these policies are not monitored.

Poverty is another challenge to access into tertiary institutions in Nigeria. Many students that are supposed to be in the Universities are not there because their parents cannot afford the huge financial cost. The little provision Government is making in terms of scholarship funds cannot reach many who are qualified to have them. Nigeria needs equitable access to higher Education as indicated by Ibrahim and Okeke (2015).

\section{Problem of Quality of Higher Education in Nigeria}

Quality here connotes standard, efficiency and reliability. The quality of Higher Education in Nigeria in terms of quality of graduates, teaching and non-teaching staff, research and development has become a subject of discussion in the print and electronic media. Many who passed through tertiary institutions only came out with certificates without substance. They have nothing to show in terms of productivity that they are graduates. This is probably why after fifty five years of independence as a nation Nigeria is still dependent on other countries for the supply of most of her basic needs. Akpandan (2015) argued that the problem of unemployment in Nigeria is not just in available spaces but in getting the right people to occupy the right positions. He further stated that many institutions produce routine graduates with routine knowledge to fit into routine jobs. The complaints about the type of graduates in the labour market today have become embarrassing to everyone in the education sector. Chineze and Olele (2011) conducted a research using UNESCO's input process and output framework for assessing the quality of education. They found out that there was low quality of input and output though the quality of process was high. Idogho (2011) in his work highlighted that the mandate of higher institutions is to develop the whole man mentally, morally and physically and to confer degrees on the products who are found worthy in character and learning to enable them assume leadership roles in their immediate and extended society. He lamented that in spite of this mandate tertiary institutions in Africa find it difficult to provide the enabling environment for the realization of this vision due to absence of quality teaching and non-teaching staff, lowered recruitment conditions for staff, proliferation of universities without the accompanying infrastructure etc. No tertiary institution can boast of quality without attending to these fundamental problems. 
Akinnaso (2012) in his article observed with regrets the poor ranking of Nigerian Universities in the world ranking of universities based on programme and instructional content. Yet Nigeria like other nations look up to the graduates of her Universities to manage the work force that will propel the nation's development. He pointed out that Nigeria's higher education problems of quality is obvious and hinges on three (3) primary problems, which are, funding, negative influence of corruptive and valueless political system and poor planning and implementation of policies. World powers today like the United States of America realized the importance of investing in manpower development through education and lavishly invested a good percentage of their income into human development and today this has translated to their rapid development.

The problems of quality in higher education in Nigeria need a pragmatic approach to tackle. Every year thousands of students graduate with only head knowledge. Laboratories in many universities cannot serve more than $20 \%$ of the student population that need them. Many lecturers are not sure of three hours of light daily in their offices where they are supposed to stay and research, majority have no internet facilities in their offices, students stand under harsh conditions to receive lectures, They live in poor and overcrowded hostel accommodation etc. The problem of hostel accommodation for students has given rise to many students staying off campus where they are exposed to several risks. It is one of the supporting factors for cultism and variety of crimes many students go into.

Apart from funding, Universities are not immune to the corruption that is almost like a label on Nigeria and Nigerians today. This has adversely affected the quality of the system in areas of recruitment, admission, appointment to managerial positions, assessment of funds from appropriate units or arms of the Government, awarding of contracts and service delivery. It will take only sincere leadership that will be ready to reverse the tide to bring quality into the system. Universities according to Okoroafor (2013) are established to carry out tripartite roles of teaching, research and community services in order to contribute meaningfully to the social and economic development of the nation. They are supposed to impact high level skills to a reasonable proportion of the work force, develop intellectual capacity of individuals and engage in training of competent and responsible professionals needed in virtually all aspects of human endeavour. Nigerian higher institutions are plagued with inadequate science and technological facilities and materials for practical skills development and this has led to graduating science and technology degree holders without commensurate practical skills. The problem of quality can also be linked to the problem of lack of need driven curriculum that will address the needs of the nation. Quality of higher education in Nigeria has been seriously affected by the problem of research and development. The primary roles of tertiary institutions are teaching, research and community service. Out of these three roles, research development makes the institutions unique. Asiabaka (2006) in his article pointed out that research is one of the engines that propel national development; he recommended the need for a well-articulated and focused research and development agenda in the country. Similarly Ifeakor and Anekwe (2012) assessed the effective utilization of educational research findings in Nigerian universities and found that research findings were underutilized. There is also the problem of manpower training and retention. All these have reduced the quality of higher education in Nigeria in every sense of it.

\section{Pragmatic approach in dealing with Access and Quality in Nigeria's higher education for Sustainable Transformation}

The current government of Nigeria has put up 'change' as its driving force. We expect that this change must reflect in every critical aspect of our national life. Higher education in Nigeria is one of such critical areas. For tertiary institutions to realize the vision of driving the work force, seasoned administrators and credible and intelligent leaders that will pilot the affairs of Nigerian nation to achieve a sustainable transformation, something unusual need to be done. This is why the writer proposes a pragmatic approach in the areas of access, quality and research development in higher education for a sustainable transformation.

\subsection{Access: Need for a pragmatic approach for sustainable Transformation}

Access as has been explained in this paper is the availability of opportunity to acquire a higher degree. Majority of Nigerians have embraced western education and are eager to go to school. The traditional policies and methods of admission which have failed to meet the needs of Nigerian nation need to give way. The policy of 45:35:20\% for merit, catchment area and educationally disadvantaged areas is unacceptable in a developing nation. The above ratio implies that only $45 \%$ of candidates seeking admission into tertiary institutions got it by merit. The question then is what stuff is the remaining 55\% made up of? Merit means that a candidate has been found fit, qualified and capable of undertaking a course of choice. If higher education will realize its vision and mandate, at list $70 \%$ of admissions should be on merit. The former ratio has over the years denied many good and promising candidates admission while mediocre have by whatever means been placed at an advantage. The quota system enshrined in the constitution of Nigeria has done more harm than good. A situation where mediocre will be preferred to people more qualified than them in the name of quota system is no longer acceptable.

The current e-exams for UTME should be improved upon and maintained to reduce many forms of examination malpractices. There should be a strong and sincere admission monitoring body from the National Universities Commission (NUC) and ministry of Education who will monitor and make sure Universities do the right thing. There should be a functional scholarship board to assist the very good and gifted students who cannot afford University education. The Board should adhere strictly to merit. Candidates for UTME should be posted to centres nearest to them and the centres should be properly equipped with computers to meet the needs of the programmes. The Government of 
former President Goodluck Jonathan created a scholarship board for first class graduates drawn from Nigerian Universities to go abroad and continue with higher degrees. This is good, but it will be better still if these gifted students should be sought for and selected at the secondary schools level so that they will be exposed early to quality University Education.

\subsection{Quality: Need for a Pragmatic Approach for a Sustainable Transformation}

Quality as earlier pointed out in this paper connotes standard, efficiency and reliability. The poor quality of some Nigerian University graduates is no longer news. The labour market is filled with some graduates that cannot perform or defend the certificate they carry. This has been a big embarrassment to the educational system. This paper advocates that this shall no longer continue. Something needs to be done. Firstly, recruitment of academic and non-academic staff into tertiary institutions should be seen as a serious business. Recruitment should be purely on merit. Recruitment exercise should involve written and oral screening that will produce the best candidates for the available positions.

There should be urgent attention to infrastructure like adequate water supply in campuses, regular power, hostel accommodation, functional libraries and good lecture halls with public address systems. Fund should be made available to address these problems. Poor hostel accommodation has led many students to live off campus and this has led to increase in students' participation in cultism, truancy and other maladaptive behaviours.

Every academic staff should be mandated to participate at least in one research programme every academic session. Facilities for enhancing teaching and learning like e-library, projectors, computers, and so on should be made available and accessible to lecturers and students. There should be an input monitoring team to monitor the activities and input of academic and non-academic staff of Nigerian tertiary institutions.

All science and technology related courses should be taught in laboratories or workshops. Practical courses should be taken seriously. Students should have good practical knowledge of what they are learning. There can never be technological breakthrough in theory based approach in teaching and learning without good practical experience. Students should have adequate exposure to practical and field experience. Research and the implementation of research findings is one approach to overcoming the poor quality of education and its effect. It is therefore imperative that research and development can no longer be treated with negligence as it has been in the past.

Research centres and tertiary institutions in Nigeria should be made to deliver their obligation. National research centres should no longer be just an avenue for employment but should really be made to carry out their responsibilities. Academic staff of tertiary institutions should have no reason to be there if they are not ready to face the challenges. Above all every research effort should be truly directed to solving or addressing a national problem.

Government should be ready to release funds for research and development. The release and utilization of such fund should be closely monitored to make sure it is used for the right purpose. Research findings and recommendations of the researchers must be appraised and utilized. This will certainly serve as a motivation for researchers. Any breakthrough in research should be made accessible to those who will benefit from them.

\section{Conclusion}

The role of higher education in the achievement of sustainable transformation in any nation cannot be over-emphasized. Higher education in Nigeria has suffered a lot of setbacks due to the problem of access, quality and research development. This has led to flooding the labour market with many weak degree holders. Many employers of labour have no confidence in some products of Nigerian's tertiary institutions. The national philosophy, goals and policy in education is good enough to realise the needed breakthrough but the poor implementation of what is on paper particularly in tertiary institutions has been the hindrance. The problems of higher education in areas of access, quality and research development are glaring and can be noticed in poor admission procedures, poor funding, corrupt recruitment processes, poor infrastructure, poor research culture and under-utilization of research findings. There is need for a pragmatic approach to address these perturbing problems. We can surely get out of the woods if the right approach can be taken and sustained.

\section{References}

Akinnaso, N. (2012). University education in Nigeria. Problems and solutions. www.punching.com. Retrieved $27^{\text {th }}$ July, 2015.

Akpandem, J. (2015). Enhancing employability of Nigerian University graduates in a competitive global economy. Premium times, November 5, 2015.

Amaele, S. (2004). The National Policy on Education and Self-reliance a histophilosophical perspective. The Nigeria Journal of Guidance and Counselling 9 (i), 54 - 70.

Asiabaka, I. P. (2006). The relevance of research and development programmes of Nigeria Universities in national development. Journal of Technology and Education in Nigeria. 11 (I) 81 -88.

Chineze, U. \& Olele, C. (2011). Academic accountability, Quality and assessment of higher education in Nigeria. Makerere Journal of Higher education, 3(2). 
Federal Republic of Nigeria (2004). National Policy on Education. NERD press.

Ibrahim, Y. A. \& Okeke, C. C. (2015). Nigerians need equitable access to higher education category. Daily Trust January $29^{\text {th }}, \operatorname{Pg} I$.

Idogho, P.O. (2011). Higher education in Nigeria and challenges ahead. European Journal of Educational studies, 3, 2.

Ifeaker, A. C. \& Anekwe, J. U. (2012). Assessment of effective utilization of educational research findings in Nigeria universities. Problems and prospects. Journal of Contemporary Research, 9(2), 28 - 40.

Okoroafor, J. (2013). Nigeria: The challenges of education, addressing the brain drain/infrastructure at www.opinion.Nigeria retrieved $27^{\text {th }}$ July, 2015.

Trading Economics (2014). Nigeria population www.TradingEconomics.com. National Bureau of Statistics Nigeria. 